\title{
EKSTRAKSI SARANG SEMUT (MYRMECODIA PENDANS) DENGAN MICROWAVE-ASSISTED EXTRACTION DAN APLIKASINYA SEBAGAI ANTIBAKTERI PADA IKAN KAKAP MERAH
}

\section{Microwave-Assisted Extraction of Ant-Nest (Myrmecodia Pendans) and its Application as Antibacterial Agents on Red Snapper}

\author{
Rahmat Yuliandri, Erryana Martati* , Agustin Krisna Wardani \\ Jurusan Teknologi Hasil Pertanian - Fakultas Teknologi Pertanian - Universitas Brawijaya \\ Jalan Veteran, Malang 65145 \\ *Penulis Korespondensi: email: erryana_m@ub.ac.id
}

Disubmit: 3 Februari 2018 Direvisi: 13 November 2018 Diterima: 11 November 2019

\begin{abstract}
ABSTRAK
Penelitian ini bertujuan untuk mengetahui pengaruh suhu dan waktu ekstraksi sarang semut (Myrmecodia pendans) dengan Microwave Assisted Extraction (MAE) terhadap rendemen, total fenol, total flavonoid, total tanin dan aktivitas antibakteri ekstrak sarang semut. Selanjutnya ekstrak sarang semut sebagai anti bakteri diaplikasikan pada ikan kakap merah (Lutjanus sanguineus). Rancangan percobaan yang digunakan yaitu Rancangan Acak Lengkap, dengan 2 faktor, yaitu suhu ekstraksi $\left(50,60\right.$ dan $\left.70^{\circ} \mathrm{C}\right)$ dan lama waktu ektraksi $(10,20$, dan 30 menit). Hasil penelitian memperoleh kondisi terbaik untuk ekstraksi sarang semut adalah suhu $70{ }^{\circ} \mathrm{C}$ dan lama waktu 20 menit. Ekstrak tersebut memiliki karakteristik antara lain rendemen 7,83\%, total fenol 150,33 mg GAE/g, total flavonoid 56,12 mg QE/g, dan total tanin 20,42 mg TAE/g. Nilai konsentrasi hambat minimum (KHM) ekstrak sarang semut pada Escherichia coli 0,5 mg/ $\mathrm{ml}$, Listeria monocytogenes $0,1 \mathrm{mg} / \mathrm{ml}$, dan Vibrio parahaemolyticus $0,5 \mathrm{mg} / \mathrm{ml}$. Selanjutnya, ekstrak diaplikasikan sebagai bahan perendaman ikan kakap yang telah dikontaminasi dengan Listeria monocytogenes. Ikan yang direndam dengan ekstrak sarang semut dan disimpan pada $4{ }^{\circ} \mathrm{C}$ dan $-8^{\circ} \mathrm{C}$ mempunyai jumlah Listeria monocytogenes yang lebih rendah dibanding dengan ikan kakap tanpa perendaman
\end{abstract}

Kata kunci : Fenol; Flavonoid; Konsentrasi Hambat Minimum; Tanin

\section{ABSTRACT}

This study aims to determine the effect of temperature and time of Microwave Assisted Extraction (MAE) of anthill (Myrmecodia pendans) to the yield, total phenol, total flavonoids, total tannins and it's antibacterial activity of extract against Escherichia coli, Listeria monocytogenes and Vibrio parahaemolyticus.. Anthill extract as anti-bacterial was applied to the red snaper ((Lutjanus sanguineus). The design experiment used was completely randomized design, with two factors, temperature of extraction $\left(50,60\right.$, and $\left.70^{\circ} \mathrm{C}\right)$ and time of extraction $(10,20$, and $30 \mathrm{~min})$. The best condition extraction was obtained at temperature $70^{\circ} \mathrm{C}$ and time of $20 \mathrm{~min}$, resulting anthill extract with characteristic as follows: a yield of 7.83\%, total phenol $150.33 \mathrm{mg}$ GAE / g, total flavonoids $56.12 \mathrm{mg} Q E / \mathrm{g}$, total tannins 20.42 TAE mg/g. Minimum concentration inhibition (MIC) on Escherichia coli, Listeria monocytogenes, and Vibrio parahaemolyticus were 0.5, 0.1 and $0.5 \mathrm{mg} / \mathrm{ml}$, respectively. Furthermore, extract was applied to soaking $(0.1 \%)$ red snapper that has been inoculated with Listeria monocytogenes and kept at -8 and $4{ }^{\circ} \mathrm{C}$. The inoculated red snapper contained a lower number of Listeria monocytogenes than un-soaked red snapper

Keywords : Minimum Concentration Inhibition; Flavonoid; Phenol; Tannin 


\section{PENDAHULUAN}

Sarang semut (Myrmecodia pendans) merupakan tumbuhan epifit yang dimanfaatkan oleh beberapa penduduk lokal di Papua sebagai obat tradisional untuk berbagai macam penyakit seperti kanker, jantung koroner, tumor, asam urat, wasir dan rematik. Sarang semut mengandung senyawa aktif yang tergolong dalam tanin terhidrolisa, flavonoid, dan tanin terkondensasi. Beberapa penelitian menunjukan bahwa sarang semut mempunyai aktivitas antibakteri terhadap Enterobacter faecalis, Staphylococcus aureus, Escherichia coli, dan Candida albicans (Situmeang et al., 2014; Efendi dan Hertiani, 2013). Hasil identifikasi ekstrak sarang semut dengan HPLC terdapat lima senyawa flavonoid yaitu kaempferol $(13,767 \mathrm{mg} / \mathrm{g})$, luteolin $(0,005$ $\mathrm{mg} / \mathrm{g})$, rutine $(0,003 \mathrm{mg} / \mathrm{g})$, quercetin $(0,030$ $\mathrm{mg} / \mathrm{g}$ ) dan apigenin $(4,700 \mathrm{mg} / \mathrm{g})$ (Engida $e t$ al., 2013).

Ekstraksi merupakan tahap paling penting untuk mendapatkan senyawa bioaktif. Metode ekstraksi konvensional memiliki kelemahan-kelemahan yaitu memakan waktu lama, membutuhkan jumah pelarut yang banyak, dan menyebabkan beberapa senyawa bioaktif terdegradasi (Baghdikian et al., 2016). Microwave Assisted Extraction (MAE) merupakan metode ekstraksi menggunakan gelombang elektromagnetik non-ion dengan frekuensi antara $300 \mathrm{MHz}$ sampai $300 \mathrm{GHz}$. Metode ekstraksi ini mempunyai keuntungan antara lain waktu ekstraksi yang singkat, menggunakan pelarut sedikit, Jika teknik ini dieksplorasi secara ilmiah, dapat menjelajah menjadi teknologi ekstraksi yang efisien dalam memastikan kualitas herbal (Mandal et al., 2007). Keuntungan ekstraksi menggunakan MAE adalah efisiensi waktu ekstraksi, peningkatan selektivitas dan hasil yang lebih tinggi dari ekstrak, reproduktifitas tinggi dalam waktu yang lebih singkat, dan mengurangi konsumsi pelarut (Baghdikian et al., 2016). Energi gelombang elektromagnetik menimbulkan iradiasi sampel dengan dipole tinggi tetapi tidak menyebabkan kerusakan sampel sehingga lebih meningkatkan efisiensi ekstrak sampel. Transfer panas yang cepat memungkinkan waktu yang jauh lebih cepat untuk sampel yang kompleks (Li et al., 2004; Engida et al., 2015).

\section{METODE}

Bahan-bahan yang digunakan yaitu: sarang semut jenis Myrmecodia pendans diperoleh dari Kabupaten Sorong Papua Barat, Ikan Kakap Merah (Lutjanus sanguineus) diperoleh dari Kecamatan Sangkapura Pulau Bawean Gresik. Isolat bakteri Escherichia coli dan Listeria monocytogenes diperoleh dari Laboratorium Pengujian Mutu Teknologi Hasil Pertanian Universitas Brawijaya. Isolat Vibrio parahaemolyticus diperoleh dari Fakultas Kedokteran Universitas Brawijaya. Asam galat (Merck), Phenol reagen (Merck), FolinCiocalteu reagen (Merck), natrium karbonat, etanol 96\%, $\mathrm{AlCl}_{3}$, Kalium Asetat, quercetin, $\mathrm{Na}_{2} \mathrm{CO}_{3}$, Media Nutrien Agar, Nutrien broth (Merck), Buffer Peptone Water (BPW), Plate Count Agar, Larutan Butterfield's Phosphate Buffered (BFP), BPW 0,1 \%, Trypticase Soy agar dengan Yeast extract (Merck).

Alat yang digunakan pada penelitian ini antara lain MAE (merk Anton Paar), oven (WTC binder), spectrophotometre UV-Vis (Shimadzu UV-mini 1240), neraca analitik (Denver Instrument M310) dan peralatan gelas.

\section{Preparasi Sampel}

Sarang semut diperoleh dari Pantai Kabupaten Sorong Papua Barat. Sampel dipotong secara melintang dengan ketebalan kurang lebih $1 \mathrm{~cm}$ selanjutnya dijemur selama 3 hari di bawah matahari. Sarang semut kering diblender sehingga berbentuk bubuk. Sampel dibungkus dengan plastik dan disimpan dalam pendingin sebelum digunakan.

\section{Ekstraksi menggunakan Microwave Assisted Extraction (MAE)}

Sebanyak $5 \mathrm{~g}$ bubuk sarang semut dilarutkan etanol 96\% kemudian diekstrak menggunakan MAE dengan kondisi suhu 50, 60 , dan $70^{\circ} \mathrm{C}$ dan lama waktu 10, 20, 30 menit. Total ada 9 kombinasi perlakuan. Ekstrak kasar disaring dengan kertas saring dan selanjutnya etanol diuapkan dengan menggunakan rotary evaporator.

\section{Analisa Total Fenol (Lee et al., 2003)}

Analisa kadar total fenol ekstrak sarang semut dilakukan dengan Folin-Ciocalteau. Sampel ekstrak sebanyak $0,4 \mathrm{ml}$ ditambah $0,4 \mathrm{ml}$ Folin-Ciocalteau dan dikocok. Setelah 5 menit tambahkan $4 \mathrm{ml} \mathrm{Na}{ }_{2} \mathrm{CO}_{3} 7 \%$. Akuades ditambahkan pada tabung reaksi 
tersebut sampai volumenya mencapai $10 \mathrm{ml}$ dan diinkubasi pada suhu $25^{\circ} \mathrm{C}$. Absorbansi dibaca dengan spektrofotometer dengan panjang gelombang $760 \mathrm{~nm}$. Kadar total fenol dinyatakan sebagai ekivalen mg asam galat.

\section{Analisa Total Flavonoid (Atanassova et al., 2011)}

Sebanyak $1 \mathrm{ml}$ sampel ekstrak ditambahkan $4 \mathrm{ml}$ akuades dan 0,3 ml NaNO $5 \%$ ke dalam tabung reaksi dan divortek hingga homogen, kemudian diinkubasi selama lima menit. Kemudian ditambahkan $0,3 \mathrm{ml} \mathrm{AlCl}_{3}$ dan diinkubasi ulang selama 6 menit dan ditambahkan $2 \mathrm{ml} \mathrm{NaOH} 1 \mathrm{M}$ dan akuades hingga mencapai volume $10 \mathrm{ml}$ dan divortek hingga homogen. Nilai serapan sampel diukur dengan panjang gelombang $510 \mathrm{~nm}$. Kadar total flavonoid dinyatakan sebagai ekivalen mg kuersetin.

Penentuan Total Tanin (Malangngi et al., 2012) Sebanyak $50 \mathrm{ml}$ sampel ditambah 2,5 $\mathrm{ml}$ etanol absolut, kemudian divorteks selama 2 menit. Selanjutnya, disentrifuse pada kecepatan $4000 \mathrm{rpm}$ selama 15 menit, lalu filtrat yang jernih diambil sebanyak $1 \mathrm{ml}$. Sebanyak $1 \mathrm{ml}$ filtrat jernih dimasukkan ke dalam labu takar $100 \mathrm{ml}$. Tambahkan $2 \mathrm{ml}$ pereaksi Folin Denis dan $5 \mathrm{ml} \mathrm{Na}{ }_{2} \mathrm{CO}_{3}$ jenuh, lalu diencerkan hingga volume $100 \mathrm{ml}$ dengan aquades. Larutan dikocok dan dibiarkan selama 40 menit. Diukur absorbansinya pada panjang gelombang $725 \mathrm{~nm}$.

\section{Penentuan Nilai Konsentrasi Hambat Mini- mum (KHM) (Doughari, 2006)}

Penentuan nilai KHM dilakukan dengan metode dilusi. Ekstrak etanol sebanyak $0,5 \mathrm{ml}$ dengan berbagai konsentrasi $(20,18,15$, $10,8,5,1,0,5$ dan $0,05 \mathrm{mg} / \mathrm{ml}$ ) dikontakkan dalam $2 \mathrm{ml}$ media NB yang telah mengandung bakteri uji. Masing-masing dimasukkan dalam tabung reaksi, kemudian diinkubasi pada suhu $37^{\circ} \mathrm{C}$ selama 24 jam. Konsentrasi ekstrak yang tidak terdapat pertumbuhan bakteri (bening) secara visual dideskripsikan sebagai nilai KHM. Konsentrasi ekstrak yang bening dicampur dengan media NA pada cawan petri, kemudian diinkubasi pada suhu $37^{\circ} \mathrm{C}$ selama 24 jam. Nilai KHM ditentukan pada konsentrasi ekstrak terkecil pada media yang tidak terdapat pertumbuhan koloni bakteri.

\section{Prosedur Inokulasi dan Aplikasi Perendaman (Gonçalves et al., 2005)}

Filet ikan kakap merah dengan ketebalan 1-2 cm sebanyak 16 sampel dan berat masing-masing sampel $150 \mathrm{~g}$ yang didapatkan dari nelayan Kecamatan Sangkapura Pulau Bawean Gresik, dibawa dengan kemasan strerofoam menggunakan es menuju Laboratorium. Masing-masing sampel dicuci menggunakan akuades steril dan dipotong secara aseptis untuk dilakukan pengujian Listeria Monocytogenes. Semua sampel disterilisasi terlebih dahulu kemudian diinokulasi bakteri dengan cara perendaman menggunakan suspensi 107 CFU/ml Listeria monocytogenes selama 10 menit pada suhu ruang.

Setelah inokulasi, sebanyak 8 sampel direndam dalam ekstrak sarang semut dengan konsentrasi 0,1\%, dan 8 sampel yang lain (kontrol) direndam dalam larutan buffer phosphate masing-masing selama 15 menit. Penirisan dilakukan selama 5 menit kemudian 3 sampel filet dengan perendaman ekstrak sarang semut disimpan pada suhu $-8^{\circ} \mathrm{C}$ dan 3 sampel lainnya pada suhu $4{ }^{\circ} \mathrm{C}$, perlakuan yang sama juga dilakukan 6 filet kontrol. Pengujian Listeria monocytogenes dilakukan kembali pada semua sampel setelah 15 dan 30 hari penyimpanan, dengan mengambil dari sebagian potongan filet dengan cara aseptis.

\section{Analisis Statistik}

Data dianalisis dengan Analysis of Variance (ANOVA) untuk mengetahui apakah ada perbedaan. Apabila hasil uji pada tiap perlakuan dan interaksi kedua perlakuan menunjukkan beda nyata maka dilakukan uji lanjut dengan Tukey Simultaneous 95\%. Penentuan perlakuan terbaik ditentukan dengan metode Technique for Order Preference by Similarity to Ideal Solution (TOPSIS).

\section{HASIL DAN PEMBAHASAN}

\section{Rendemen}

Rerata nilai rendemen dengan perlakuan suhu dan lama ekstraksi dapat dilihat pada Gambar 1. Hasil analisa ragam menunjukkan bahwa faktor suhu dan lama waktu reaksi berpengaruh nyata $(\alpha=0,05)$ terhadap nilai rendemen dan terjadi interaksi antara faktor suhu dan lama waktu ekstraksi terhadap nilai rendemen ekstrak. 


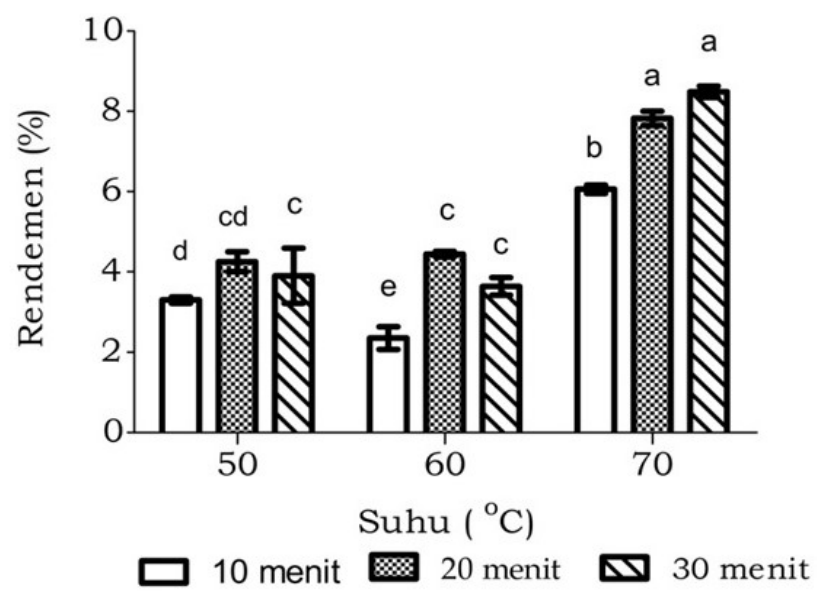

Gambar 1. Pengaruh suhu dan waktu ekstraksi terhadap rerata rendemen ekstrak sarang semut

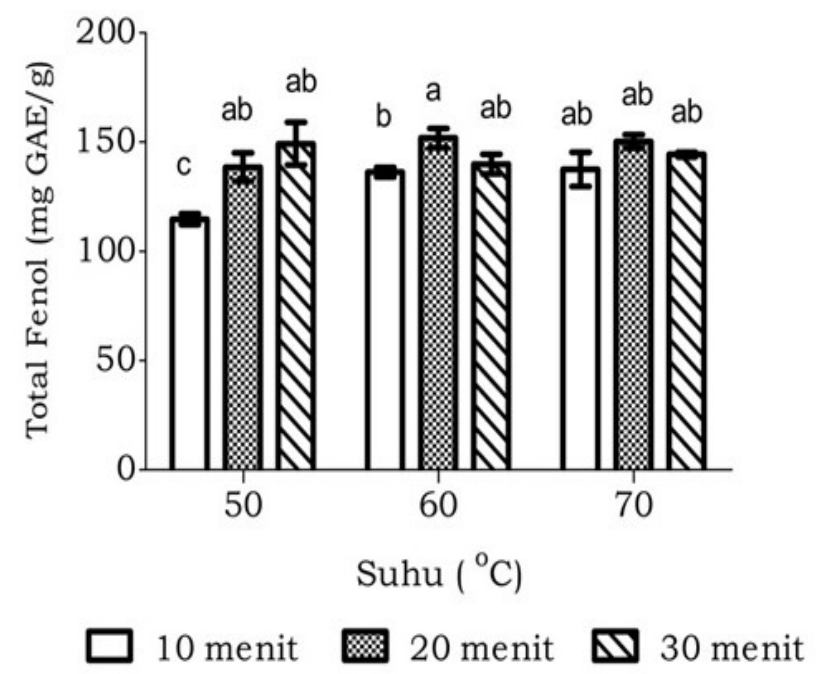

Gambar 2. Pengaruh suhu dan waktu ekstraksi terhadap rerata total fenol ekstrak sarang semut

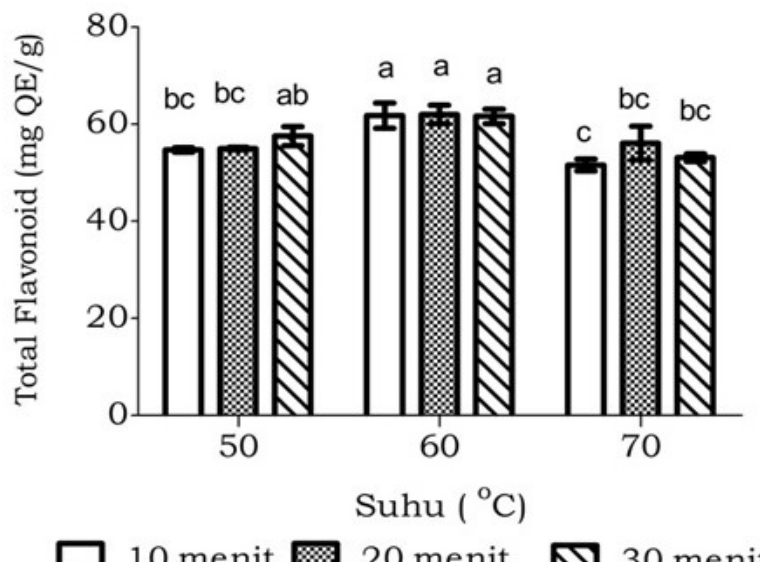

Gambar 3. Pengaruh suhu dan waktu ekstraksi terhadap rerata total flavonoid ekstrak Sarang semut 
Ekstraksi pada suhu $70{ }^{\circ} \mathrm{C}$ menghasilkan rendemen lebih besar dari pada suhu 60 ${ }^{\circ} \mathrm{C}$ dan $50^{\circ} \mathrm{C}$. Energi gelombang elektromagnetik dan panas akan diserap oleh pelarut yang selanjutnya mencapai dinding sel, pada gilirannya membantu pelarut untuk mengakses solut dalam matriks bahan. Rendemen tertinggi dihasilkan oleh perlakuan MAE dengan suhu $70{ }^{\circ} \mathrm{C}$, dengan waktu terbaik secara berurutan yaitu 30, 20, dan 10 menit. Rendemen terendah dihasilkan oleh perlakuan ekstraksi pada suhu $50{ }^{\circ} \mathrm{C}$ selama 10 menit. Ekstraksi pada suhu yang lebih rendah dan waktu yang lebih pendek menghasilkan jumlah solut yang lebih rendah dibanding ekstraksi pada suhu yang lebi tinggi dan waktu yang lebih lama.

\section{Total Fenol}

Rerata total fenol dengan perlakuan suhu dan lama ekstraksi dapat dilihat pada Gambar 2. Hasil analisa ragam menunjukkan bahwa faktor suhu dan lama waktu reaksi berpengaruh nyata $(\alpha=0,05)$ terhadap nilai total fenol dan terjadi interaksi antara faktor suhu dan lama waktu ekstraksi terhadap nilai total fenol.

Perlakuan terbaik yang menghasilkan total fenol tertinggi terdapat pada perlakuan ekstraksi dengan suhu $60^{\circ} \mathrm{C}$ selama 20 menit dan diikuti oleh perlakuan ekstraksi dengan suhu $70^{\circ} \mathrm{C}$ selama 20 menit. Hal ini didukung oleh penelitian Liazid et al. (2007), yang menyarankan penggunaan waktu 20 menit untuk mendapatkan total fenol terbaik, dikarenakan pada waktu yang lebih lama akan mengakibatkan degradasi beberapa komponen penyusun fenol tersebut. Total fenol terendah dialami oleh perlakuan ekstraksi dengan suhu $50{ }^{\circ} \mathrm{C}$ selama 10 menit. Ekstraksi pada suhu $50{ }^{\circ} \mathrm{C}$ mengalami kenaikan total fenol seiring dengan meningkatnya waktu ekstraksi dari 10, 20, dan 30 menit menghasilkan total fenol yang semakin tinggi. Pada suhu 60 dan $70{ }^{\circ} \mathrm{C}$ total fenol dalam jumlah yang tertinggi berada pada ekstraksi dengan waktu 20 menit dan mengalami penurunan pada ekstraksi dengan waktu 30 menit. Tiap jenis tumbuhan mempunyai sensitivitas fenol pada suhu yang berbeda-beda karena jenis fenol berbeda pada masing-masing tanaman (Junior et al., 2010). Hasil penelitian Akbari et al. (2019) menujukkan bahwa suhu hingga suhu $80^{\circ} \mathrm{C}$ akan mengingkat kadar total fenol ekstraksi dengan MAE bahan klabet (Trigonella foenum-graecum).

\section{Total Flavonoid}

Rerata total flavonoid dengan perlakuan suhu dan lama ekstraksi dapat dilihat pada Gambar 3. Hasil analisa ragam menunjukkan bahwa faktor suhu berpengaruh nyata $(\alpha=0,05)$ terhadap nilai total flavonoid, sedangkan lama waktu ekstraksi tidak berpengaruh nyata dan tidak ada interaksi antara faktor suhu dan lama waktu ekstraksi terhadap nilai total flavonoid.

Perlakuan terbaik terjadi pada perlakuan dengan menggunakan suhu ekstraksi $60^{\circ} \mathrm{C}$ dengan waktu ekstraksi 20 menit. Nilai total flavonoid tersebut lebih tinggi dari hasil penelitian Sanjaya et al. (2014) yang melakukan ekstraksi sarang semut dengan metode supercritical extraction dengan suhu $70^{\circ} \mathrm{C}$ dan dari beberapa macam perlakuan waktu (6-7 jam). Suhu memberikan pengaruh yang nyata pada total flavonoid. Secara umum, pada tiap-tiap waktu ekstraksi yang sama, total flavonoid meningkat dengan meningkatnya suhu dari 50 ke $60{ }^{\circ} \mathrm{C}$, dan total flavonoid menurun dengan meningkatnya suhu dari 60 ke $70^{\circ} \mathrm{C}$. Penelitian ekstraksi Perilla frutescens menggunakan MAE pada suhu 60-140 ${ }^{\circ} \mathrm{C}$ dan didapatkan bahwa total flavonoid mengalami penurunan stabilitas dengan semakin meningkatnya suhu dimulai dari 60 ${ }^{\circ} \mathrm{C}$ (Meng et al., 2009; Shao et al., 2012).

\section{Total Tanin}

Rerata total tanin dengan perlakuan suhu dan lama ekstraksi dapat dilihat pada Gambar 4. Hasil analisa ragam menunjukkan bahwa faktor suhu berpengaruh nyata $(a=0,05)$ terhadap nilai total tanin, sedangkan lama waktu ekstraksi tidak berpengaruh nyata dan tidak ada interaksi antara faktor suhu dan lama waktu ekstraksi terhadap nilai total tanin.

Total tanin meningkat dari waktu ekstraksi 10 menit ke 20 menit dan menurun dari 20 menit ke 30 menit, baik pada suhu 50,60 , dan $70^{\circ} \mathrm{C}$. Hal ini didukung oleh penelitian Jing dan Giusti (2007), yang mengekstraksi Purple corn dengan suhu kamar, 50, 75 , dan $100^{\circ} \mathrm{C}$ dan mendapatkan bahwa total tanin meningkat seiring dengan peningkatan suhu ekstraksi pada kisaran suhu tersebut. Senyawa tanin mempunyai aktivitas antibakteri Listeria monocytogenes (Roger et al., 2018).

\section{Konsentrasi Hambat Minimum \\ Konsentrasi Hambat Minimum (KHM) ekstrak sarang semut dari berbagai}


Jurnal Teknologi Pertanian Vol. 20 No. 3 [Desember 2019] 193-202

Ekstraksi Sarang Semut (Myrmecodia pendans) dengan Microwave Assisted Extraction [Yuliandri dkk]

Tabel 1. KHM ekstrak sarang semut terhadap Escherichia coli, V. parahaemolyticus, dan Listeria monocytogenes

\begin{tabular}{ccccc}
\hline \multicolumn{2}{c}{ Perlakuan } & \multicolumn{3}{c}{ KHM $(\mathbf{m g} / \mathbf{m l})$} \\
\hline Suhu $\left({ }^{\circ} \mathbf{C}\right)$ & Waktu (Menit) & $\boldsymbol{V P}$ & $\boldsymbol{L M}$ & EC \\
\hline 50 & 10 & 1,0 & 0,83 & 5,0 \\
& 20 & 0,83 & 0,5 & 1,0 \\
60 & 30 & 0,83 & 0,5 & 1,0 \\
& 10 & 1,0 & 0,5 & 5 \\
70 & 20 & 0,83 & 0,5 & 1,0 \\
& 30 & 0,83 & 0,5 & 1,0 \\
& 10 & 1,0 & 0,5 & 5,0 \\
& 20 & 0,5 & 0,1 & 0,5 \\
& 30 & 0,5 & 0,1 & 0,5 \\
\hline
\end{tabular}

Keterangan: VP adalah V. parahaemolyticus; LM adalah Listeria monocytogenes; EC adalah Escherichia coli

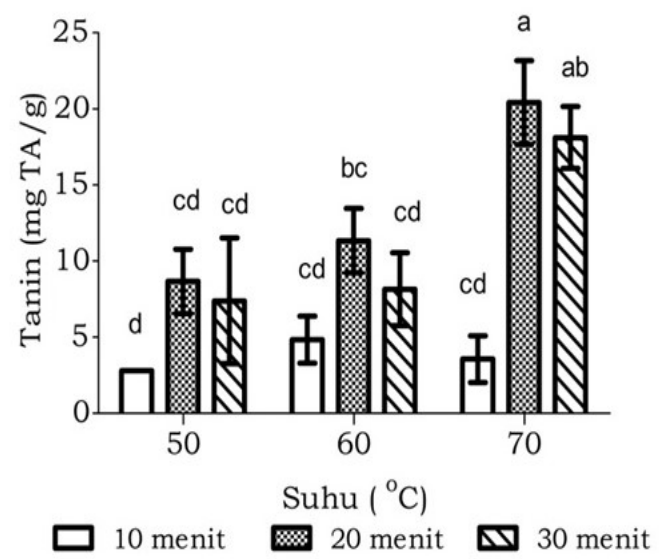

Gambar 4. Pengaruh suhu dan waktu ekstraksi terhadap rerata total tanin ekstrak sarang semut

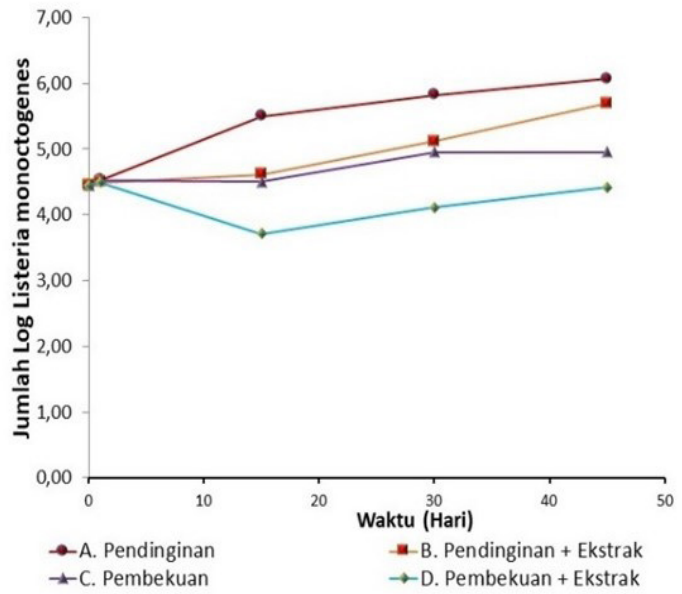

Gambar 5. Pengaruh perendaman filet ikan kakap dalam ekstrak sarang semut dan suhu penyimpanan terhadap jumlah Listeria monocytogenes: A. pendinginan suhu $4{ }^{\circ} \mathrm{C}$ tanpa perendaman ekstrak, B. pendinginan suhu $4^{\circ} \mathrm{C}$ dengan perendaman ekstrak, C. pembekuan suhu $-8{ }^{\circ} \mathrm{C}$ tanpa perendaman ekstrak, D. pembekuan suhu $-8{ }^{\circ} \mathrm{C}$ dengan perendaman ekstrak sebelum penyimpanan 
perlakuan ekstrak menggunakan MAE ditunjukkan pada Tabel 1. Hasil analisis statistika menunjukkan KHM ekstrak etanol sarang semut menunjukkan perbedaan KHM yang nyata antara ketiga jenis bakteri tersebut. Nilai KHM ekstrak dari yang tertinggi ke yang lebih rendah secara berurutan yaitu terhadap Escherichia coli, V. parahaemolyticus, dan Listeria monocytogenes. Hal ini berarti bahwa dibutuhkan konsentrasi ekstrak sarang semut yang lebih besar untuk menghambat pertumbuhan Escherichia coli, dan V. parahaemolyticus daripada Listeria monocytogenes. Bakteri Escherichia coli, dan V. parahaemolyticus yang merupakan bakteri gram negatif cenderung lebih tahan dari pada Listeria monocytogenes yang merupakan bakteri gram positif. Perbedaan sensitivitas ketiga jenis bakteri tersebut disebabkan oleh perbedaan struktur membran dinding sel antara bakteri gram positif dengan negatif. Bakteri gram positif mempunyai lapisan lipo polisakarida eksternal dan tambahan komponen membran minor selain membran plasma utuh sekitar sel yang memiliki potensi hidrofobisitas dan karena itu bisa menciptakan lingkungan yang tidak menguntungkan bagi fenolat sederhana untuk menciptakan efek pengasaman (Vattem et al., 2004).

Bakteri Genus Vibrio sangat rentan terhadap polifenol. Nilai KHM 10 jenis polifenol terhadap 4 grup bakteri diantaranya genus Vibrio. Bakteri Genus Vibrio paling rentan terhadap polifenol daripada Escherichia coli, Salmonella dan Staphylococcus aureus, dimana Genus Vibrio mempunyai KHM terendah (Taguri et al., 2004). Berdasarkan 10 jenis polifenol yang diteliti tersebut, diantaranya senyawa epigallocatechin, procyanidin, tanin terdapat pada tumbuhan sarang semut jenis Myrmecodia pendans (Agatonovic-Kustrin et al., 2018). Bakteri Escherichia coli, mempunyai kemampuan dalam menanggulangi tekanan yang disebabkan oleh asam (Taguri et al., 2004). Bakteri enterohemorrahagic termasuk E. coli mempunyai kemampuan untuk mengelola stress karena asam dengan cara menyebarkan proton dengan jalan memperpanjang membran sel mereka. Selain itu menurut Vattem et al. (2004), beberapa antioksida hidrofobik dimungkinkan dapat merusak sistem keseimbangan sel $V$. parahaemolyticus dengan menghambat fungsi saluran ion yang biasa digunakan oleh bakteri ini untuk mempertahankan diri pada lingkungan kadar garam tinggi (Lin et al., 2004).
Ekstrak sarang semut mempunyai KHM yang berbeda-beda terhadap E.coli, dimana ekstrak dengan perlakuan MAE suhu $70{ }^{\circ} \mathrm{C}$ selama 20 dan 30 menit mempunyai KHM terbaik terhadap Escherichia coli, yaitu sebesar 0,5 mg/ml. Hal ini mempunyai korelasi dengan kandungan total tanin yang dimiliki oleh kedua perlakuan tersebut, dimana kedua perlakuan tersebut memiliki total tanin tertinggi pertama dan kedua diantara kesembilan perlakuan ekstraksi MAE.

\section{Pengaruh Perendaman Ikan Kakap dalam Ekstrak Sarang Semut Terhadap Pertumbu- han Listeria monocytogenes}

Pada Gambar 5 menunjukkan jumlah peningkatan jumlah bakteri yang tertinggi dialami oleh sampel dengan perlakuan penyimpanan $4^{\circ} \mathrm{C}$ tanpa perendaman ekstrak, kemudian diikuti secara berurutan oleh sampel perlakuan penyimpanan $4{ }^{\circ} \mathrm{C}$ dengan perendaman ekstrak, sampel perlakuan penyimpanan dingin tanpa perendaman ekstrak, dan sampel perlakuan penyimpanan $-8{ }^{\circ} \mathrm{C}$ dengan perendaman ekstrak. Pada penyimpanan suhu $-8{ }^{\circ} \mathrm{C}$, jumlah Listeria monocytogenes pada sampel dengan perlakuan perendaman ekstrak dan tanpa perendaman ekstrak terdapat perbedaan nyata, pada penyimpanan $-8{ }^{\circ} \mathrm{C}$ dan sampel direndam ekstrak memiliki pertumbuhan jumlah Listeria monocytogenes yang lebih rendah. Sampel yang tidak mengalami perlakuan perendaman ekstrak memiliki kenaikan jumlah sel yang lebih tinggi dari pada sampel yang direndam pada ekstrak selama penyimpanan. Ekstrak sarang semut yang mengandung beberapa senyawa fitokimia memberikan efek penghambatan bagi pertumbuhan bakteri. Asam tanat mempunyai daya hambat pada uji cakram terhadap bakteri dikarenakan asam tanat dapat menghancurkan integritas dinding sel selanjutnya asam tanat bisa mempengaruhi pembentukan bio-film (Dong et al., 2018). Penyimpanan beku ikan salmon yang diinokulasi Listeria monocytogenes dapat menurunkan jumlah sel 1 sampai $2 \log 10 \mathrm{cfu} / \mathrm{g}$ pada hari ke 30 penyimpanan beku. Selama pembekuan, bakteri Listeria monocytogenes mengalami penyusutan ukuran sel dan mengalami evolusi karakter biokimia, dimana beberapa enzim (D-arabitol, D-xylose, L-rhamnose, a-methyl-D-glucoside, D-ribose, glucose-1-phosphate, dan D-tagatose) memproduksi asam (Miladi et al., 2008). Pada penyimpanan suhu $4^{\circ} \mathrm{C}$, jumlah Listeria monocytogenes sampel dengan perlakuan 
perendaman ekstrak dan tanpa perendaman ekstrak terdapat perbedaan nyata jumlah bakteri. Sampel dengan perendaman ekstrak memiliki pertumbuhan jumlah bakteri yang lebih rendah. Pada hari ke-30, sampel dengan perendaman ekstrak memiliki jumlah Listeria monocytogenes lebih rendah $0,84 \log 10 \mathrm{cfu} / \mathrm{g}$, dan pada hari ke 45 lebih rendah $0,54 \log 10$ $\mathrm{cfu} / \mathrm{g}$ dibandingkan dengan sampel tanpa perendaman ekstrak. Tanin terutaman asam tanat diketahui mempunyai aktivtas antibakteri yang efektif. Mekanisme sebagai antibakteri antara lain mengkelat ion logam terutama besi $(\mathrm{Fe})$ menyebabkan stres oksidatif sel (Roger et al., 2018). Sampel tanpa perendaman menunjukkan peningkatan jumlah sel dari 28x104 cfu/g (hari ke-0) hingga diatas $107 \mathrm{cfu} / \mathrm{g}$ pada (hari ke-45). Hal ini sejalan penelitian lain yang menunjukkan pertumbuhan Listeria monocytogenes mengalami peningkatan sebesar $1 \log 10 \mathrm{cfu} / \mathrm{g}$ dari hari ke-0 hingga hari ke-8 pada ikan tanpa perlakuan perendaman dan disimpan pada suhu $4{ }^{\circ} \mathrm{C}$. Pada penelitian tersebut, dinyatakan bahwa kandungan fenol yang terdapat dalam ekstrak Oregano berperan dalam menurunkan jumlah sel sejumlah $3 \log 10 \mathrm{cfu} / \mathrm{g}$ pada hari ke-8 (Lin et al., 2004). Listeria monocytogenes masih mempunyai kemampuan tumbuh pada suhu $2-5^{\circ} \mathrm{C}$. Ikan yang diinokulasi Listeria monocytogenes kemudian disimpan pada suhu $4{ }^{\circ} \mathrm{C}$, setelah 15 hari mengalami kenaikan jumlah sel sejumlah 0,9 log10 cfu/g. Kenaikan ini lebih kecil dari pada ikan yang disimpan pada suhu $25^{\circ} \mathrm{C}$ (Miladi et al., 2008). Pada penelitian tersebut, pada hari ke-45, sampel perlakuan dingin tanpa perendaman tersebut mengalami fase stationer, ditunjukkan oleh grafik yang horizontal, sedangkan pada sampel penyimpanan dingin dengan perendaman ekstrak masih menunjukkan peningkatan jumlah sel (fase log). Bagian fenolik yang bersifat hidrofobik memungkinkan penempelan pada membran sitoplasma bakteri yang pada akhirnya akan mengakibatkan kematian sel. Bagian hidrofobik alami yang dimiliki oleh senyawa fenolik mampu bekerja secara lebih efektif dalam menghadapi bagian lipid dan air dalam daging, sehingga cocok diaplikasikan dalam makanan (Lin et al., 2004).

\section{SIMPULAN}

Kondisi terbaik ekstraksi sarang semut dengan MAE adalah kombinasi perlakuan suhu $70{ }^{\circ} \mathrm{C}$ selama 20 menit. Ekstrak yang dihasilkan mempunyai karakteristik sebagai berikut: rendemen $7,83 \%$, total fenol 150,33 mg GAE/g, total flavonoid 56,12 mg QE/g, total tanin 20,42 mg TAE/g. Nilai KHM pada Escherichia coli $0,5 \mathrm{mg} / \mathrm{ml}$, Listeria monocytogenes $0,1 \mathrm{mg} / \mathrm{ml}$ dan $V$. parahaemolyticus $0,5 \mathrm{mg} / \mathrm{ml}$. Filet ikan yang direndam dalam ekstrak sarang semut memiliki pertumbuhan jumlah Listeria monocytogenes yang berbeda signifikan dan lebih rendah dari pada filet ikan yang tidak direndam dalam ekstrak sarang semut.

\section{DAFTAR PUSTAKA}

Agatonovic-Kustrin, -S., Morton, D, -W., Mizaton, $\mathrm{H},-\mathrm{H}$., Zakaria, -H., 2018. The relationship between major polyphenolic acids and stigmasterol to antioxidant activity in different extracts of Myrmecodia platytyrea. South African Journal of Botany. 115, 94-99. https:// doi.org/10.1016/j.sajb.2017.12.011

Akbari, -S., Abdurahman, N, -H., Yunus, R, -M., Fayasz, -F., 2019. Microwave assisted extraction of saponin, phenolic and flavonoid from Trigonella foenum-graecu, seed based on two level factorial. Journal of Applied Research on Medicinal and Aromatic Plants. 14, 100212. https://doi.org/10.1016/j.jarmap.2019.100212

Atanassova, -M., Georgieva, -S., Ivancheva, -K., 2011. Total phenolic and total flavonoid contents, antioxidant capacity and biological contaminants in medicinal herbs. Journal of the University of Chemical Technology and Metallurgy. 46(1), 81-88. https://pdfs.semanticscholar.org/42a7/ab099e68a0c6301bef90180e1e4d31900932.pdf

Baghdikian, -B., Filly, -A., Fabiano-Tixier, A. -S., Petitcolas, -E., Mabrouki, -F., Chemat, -F., Ollivier, -É., 2016. Extraction by solvent using microwave and ultrasound-assisted techniques followed by HPLC analysis of Harpagoside from Harpagophytum Procumbens and comparison with conventional 
solvent extraction methods. Comptes Rendus Chimie. 19(6), 692-698. https:// doi.org/10.1016/j.crci.2016.02.020

Dong, -G., Liu, -H., Yu, -X., Zhang, -X., Lu, -G., Zhou, -T., Cao, -J., 2018. Antimicrobial and anti-biofilm activity of tannic acid against Staphylococcus aureus. Natural Product Research. 32, 2225-2228. https:// doi.org/10.1080/14786419.20 17.1366485

Doughari, J, -H., 2006. Antimicrobial activity of Tamarindus indica Linn. Tropical Journal of Pharmaceutical Research. 5(2), 597-603. http://dx.doi.org/10.4314/ tjpr.v5i2.14637

Efendi, Y, -N., Hertiani, -T., 2013. Antimicrobial potency of ant-plant extract (Myrmecodia tuberosa Jack) against Candida albicans, Escherichia coli, and Staphylococcus aureus. Majalah Obat Tradisional. 18(1), 53-5. https://doi. org/10.22146/tradmedj.7944

Engida, A, -M., Faika, -S., Nguyen-Thi, B, -T., Ju, Y, -H., 2015. Analysis of major antioxidants from extracts of Myrmecodia pendans by UV/visible spectrophotometer, liquid chromatography/ tandem mass spectrometry, and highperformance liquid chromatography/ UV techniques. Journal of Food and Drug Analysis. 23(2), 303-309. https:// doi.org/10.1016/j.jfda.2014.07.005

Engida, A, -M., Kasim, N, -S., Tsigie, Y, -A., Ismadji, -S., Huynh, L, -H., Ju, Y, -H., 2013. Extraction, identification and quantitative HPLC analysis of flavonoids from sarang semut (Myrmecodia pendan). Industrial Crops and Products. 41 (1), 392-396. https://doi. org/10.1016/j.indcrop.2012.04.043

Gonçalves, A, -C., Almeida, R, C, -C., Alves, M, -A, -O., Almeida, P, -F., 2005. Quantitative investigation on the effects of chemical treatments in reducing Listeria monocytogenes populations on chicken breast meat. Food Control.16(7), 617-622. https://doi.org/10.1016/j. foodcont.2004.06.026

Jing, -P., Giusti, M, -M., 2007. Effects of extraction conditions on improving the yield and quality of an Anthocyaninrich purple corn (Zea mays L.) color extract. Journal of Food Science. 72(7), C363-C368. https://doi.org/10.1111/ j.1750-3841.2007.00441.x
Junior, M, R, -M., Leite, A, -V., Dragano, N, R, -V., 2010. Supercritical fluid extraction and stabilization of phenolic compounds from natural sources-review (supercritical extraction and stabilization of phenolic compounds). The Open Chemical Engineering Journal. 4, 51-60. https://doi. org/10.2174/1874123101004010051

Lee, K, -W., Kim, Y, -J., Lee, H, -J., Lee, C, -Y., 2003. Cocoa has more phenolic phytochemical and higher antioxidant than teas and red wine. Journal of Agricultural and Food Chemistry. 51(25), 249-252. https:// doi.org/10.1021/jf0344385

Li, M, -J., You, J, -Y., Yao, -S., Ding, -L., Liu, Z, -Y., Zhang, H, -Q., 2004. Microwave-assisted extraction of rutin and quercetin from flos sophorae. Chemical Research in Chinese Universities. 20, 703-706

Liazid, -A., Palma, -M., Brigui, -J., Barroso, C, -G., 2007. Investigation on phenolic compounds stability during microwave-assisted extraction. Journal of Chromatography A.1140, 29-34. https:/ / doi.org/10.1016/j.chroma.2006.11.040

Lin, Y, -T., Labbe, R, -G., Shetty, -K., 2004. Inhibition of Listeria monocytogenes in fish and meat systems by use of oregano and cranberry phytochemical synergies. Applied and Environmental Microbiology. 70(9), 5672-5678. https:// dx.doi.org/10.1128\%2FA EM.70.9.5672-5678.2004

Malangngi, -L., Sangi, -M., Paendong, -J., 2012. Penentuan kandungan tanin dan uji aktivitas antioksidan ekstrak biji buah alpukat (Persea americana Mill.). Jurnal Mipa Universitas Sam Ratulangi. 1(1), 5-10. https://doi.org/10.35799/ jm.1.1.2012.423

Mandal, -V., Mohan, -Y., Hemalatha, -S., 2007. Microwave assisted extraction an innovative and promising extraction tool for medicinal plant research. Pharmacognosy Reviews. 1(1), 7-18. https://www.phcogrev.com/article/2007/1/1-0

Meng, -L., Lozano, -Y., Bombarda, -I., Gaydou, E, -M., Li, -B., 2009. Polyphenol extraction from eight Perilla frutescens cultivars. Comptes Rendus Chimie. 12(5), 602-611. https://doi.org/10.1016/j. crci.2008.04.011 
Miladi, -H., Chaieb, -K., Bakhrouf, -A., Elmnasser, -N., Ammar, -E., 2008. Freezing effects on survival of Listeria monocytogenes in artificially contaminated cold fresh-salmon. Annals of Microbiology. 58(3), 471-476. https://doi. org/10.1007/BF03175545

Roger, J, -A., Magro, -M., Spagnolo, -S., Bonaiuto, -E., Baratella, -D., Fasolato, -L., Vianello, -F., 2018. Antimicrobial and magnetically removable tannic acid nanocarrier: A processing aid for Listeria monocytogenes treatment for food industry applications. Food Chemistry. 26, 430-436. https://doi.org/10.1016/j. foodchem.2017.06.109

Sanjaya, R, -E., Tedjo, Y, -Y., Kurniawan, -A., Ju, Y, -H., Ayucitra, -A., Ismadji, -S., 2014. Investigation on supercritical $\mathrm{CO}_{2}$ extraction of phenolic-phytochemicals from an epiphytic plant tuber (Myrmecodia pendans). Journal of CO2 Utilization. 6, 26-33. https://doi.org/10.1016/j. jcou.2014.03.001

Situmeang, B., Kurnia, D., Sumiarsa, D., Dharsono, H, A., Satari, M. 2014. Pentacyclic triterpenes from sarang semut tuber
(Myrmecodia pendans) and their antibacterial activity test against Escherichia coli. Prosiding Seminar Nasional MIPA, Universitas Padjajaran. Bandung, pp. 63-67

Shao, -P., He, -J., Sun, -P., Zhao, -P., 2012. Analysis of conditions for microwaveassisted extraction of total water-soluble flavonoids from Perilla Frutescens leaves. Journal of Food Science and Technology. 49(1), 66-73. https://dx.doi. org/10.1007\%2Fs13197-011-0265-8

Taguri, -T., Tanaka, -T., Kouno, -I., 2004. Antimicrobial activity of 10 different plant polyphenols against bacteria causing food-borne disease. Biological and Pharmaceutical Bulletin. 27(12), 1965-1969. https://doi.org/10.1248/bpb.27.1965

Vattem, D, -A., Lin, Y, -T., Labbe, R, -G., Shetty, -K., 2004. Phenolic antioxidant mobilization in cranberry pomace by solid-state bioprocessing using food grade fungus Lentinus edodes and effect on antimicrobial activity against select food borne pathogens. Innovative Food Science \& Emerging Technologies. 5(1), 81-91. https://doi.org/10.1016/j. ifset.2003.09.002 